\title{
DEVELOPMENT OF THE DOUBLE THREAD CHAIN STICH SEWING MACHINE WITH REVERSE MOVEMENT
}

In the work, we propose the algorithm of modernization of a specific chain stitch sewing machine, as a result of which significant expansion of technological possibilities of this machine is possible. In this work, the essence of the problem solved through the modernization, the composition and structure of devices, which need to be mounted in the machine, and their connection with the existing mechanisms of the machine, are developed. In addition, we provide the calculation of the main dimensional parameters of devices that provide reliable operation of the machine in both modes, as well as the troublefree transition from one mode to another.

Keywords: sewing machine, fastening, chain stitch, reverse movement.

О.П. МАНОЙЛЕНКО, В.А. ГОРОБЕЦЬ, Д.О. НЕННО

Київський національний університет технологій та дизайну

\section{РОЗРОБКА ШВЕЙНОЇ МАШИНИ ДВОНИТКОВОГО ЛАНЦЮГОВОГО СТІБКА 3 РЕВЕРСОМ}

В роботі розглянутий алгоритм модернізації конкретної сточувальної швейної машини ланцюгового стібка, в результаті якої можливе суттєве розширення ї̈ технологічних можливостей. В роботі розкрита суть проблеми, яка вирішується при модернізації, розроблена структура та будова пристроїв, які необхідно вмонтувати в машину та показаний їх зв'язок з існуючими механізмами машини. Крім того в роботі виконаний розрахунок основних розмірних параметрів даних пристроїв, які забезпечують надійну роботу машини в обох режимах, а також безпроблемний перехід з одного режиму в інший.

Ключові слова: швейна машина, закріпка, ланцюговий стібок, реверсивний рух.

In case of the increase in the range of elastic materials, sewing machines of double thread chain stitch are widely used in relation to the known advantages of chain stitches. However, their propensity to break loose in the absence of the possibility of securing the ends of the rows by reversing the movement of cross-linked materials substantially hamper the further implementation of this type of equipment.

The main problem that arises in the reverse transportation of materials is the impossibility of providing the so-called "pierce" of the looper (L) loop with a needle (N) (fig. 1, a), or rather the needle's (N) hit in the "thread triangle" formed by the branches of the looper loop and the previous thread loop of the needle. There are several ways to solve this problem: the formation of a "thread triangle" with flow of air (F) (fig. 1, b) in the reverse, the use of additional tools - expanders (one or two) (fig. 1, c) [1, 2] or shutdown of the looper movement during the reverse (fig. 1, d) [3]. In practice, the last two methods have been used.

Therefore, in the work [4] they propose a double thread chain stich sewing machine with reverse movement of the material, where the stitch in the formation of fasteners is formed by disabling the longitudinal movement of the loop. However, the presence in the design of the mechanism of the lover of an elastic link, which constantly works at an angular speed of the main shaft of the machine 300-400 s $\mathrm{s}^{-1}$, can lead to a violation of the interaction of the loop with a needle, where the accuracy of the positioning is $0.1 \mathrm{~mm}$. In addition, the need to design and embed a reversing device in machine, which the chain machines do not have in principle, significantly complicates and raises the machine. This can be seen on a similar machine developed by Juki (Japan) [5] several years ago. Due to the fact that it has additionally the mechanism of the diversion, besides of the mechanism of the looper also, as well as the already mentioned mechanism of reversal, the price of even the basic design is 3800 euros, and equipped with auxiliary devices - 5200 euros.

At the same time, the country has a sufficient number of fully working sewing machines of a constructive number $876 \mathrm{PMZ}$, whose prices in the secondary market is about $1000 \mathrm{UAH}$ per unit.

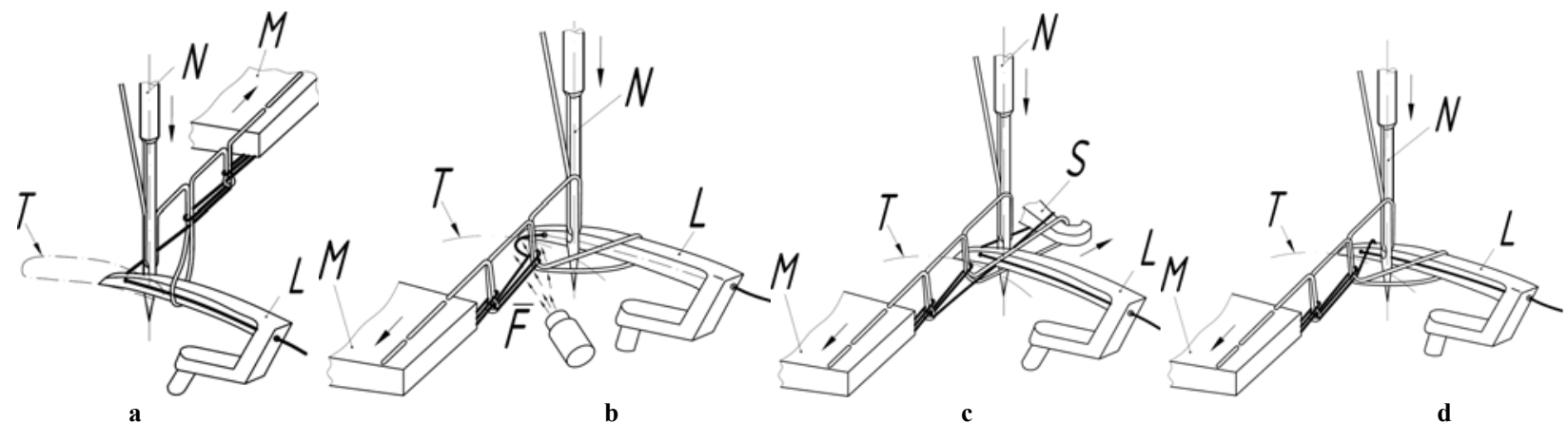

Fig. 1. The method of forming a "thread triangle": a - with direct movement of materials; $b$ - by an air flow with reverse movement of materials; $c$ - by extender in reverse movement of materials; $d$ - by turning off the looper movement along the line

The authors, on the basis of those machines developed a sewing machine with a reverse, by reconstruction 
of the looper mechanism (fig. 2, a, b) (options 1 and 2), in which the ellipsoid trajectory of the looper point (D) is obtained only by the kinematic chain of its transverse displacements and in which a switching device to turn off those movements of the looper is provided.

The reverse of material movement is done due to a change in the direction of rotation of the main shaft 1 , for example, according to the classical circuitry of asynchronous motor reverse (fig. 3) when the lever 4 is pressed to turn off the looper movement (fig. 2) and pressing the S1 switch. The supply of the thread to the looper on the reverse is provided by an additional thread-giving cam 11, which is mirrored 10 and on which lower thread enters in the reverse by transferring it to the area of thread-giving cam 11 by a thread-fixing unit 9 , which occupies a corresponding position using the levers 4 and 8 , which are connected by thrust 7 .

Thus, with the help of simple modernization, it is possible to obtain equipment with an important additional function, and which has a simpler design than the base machine.
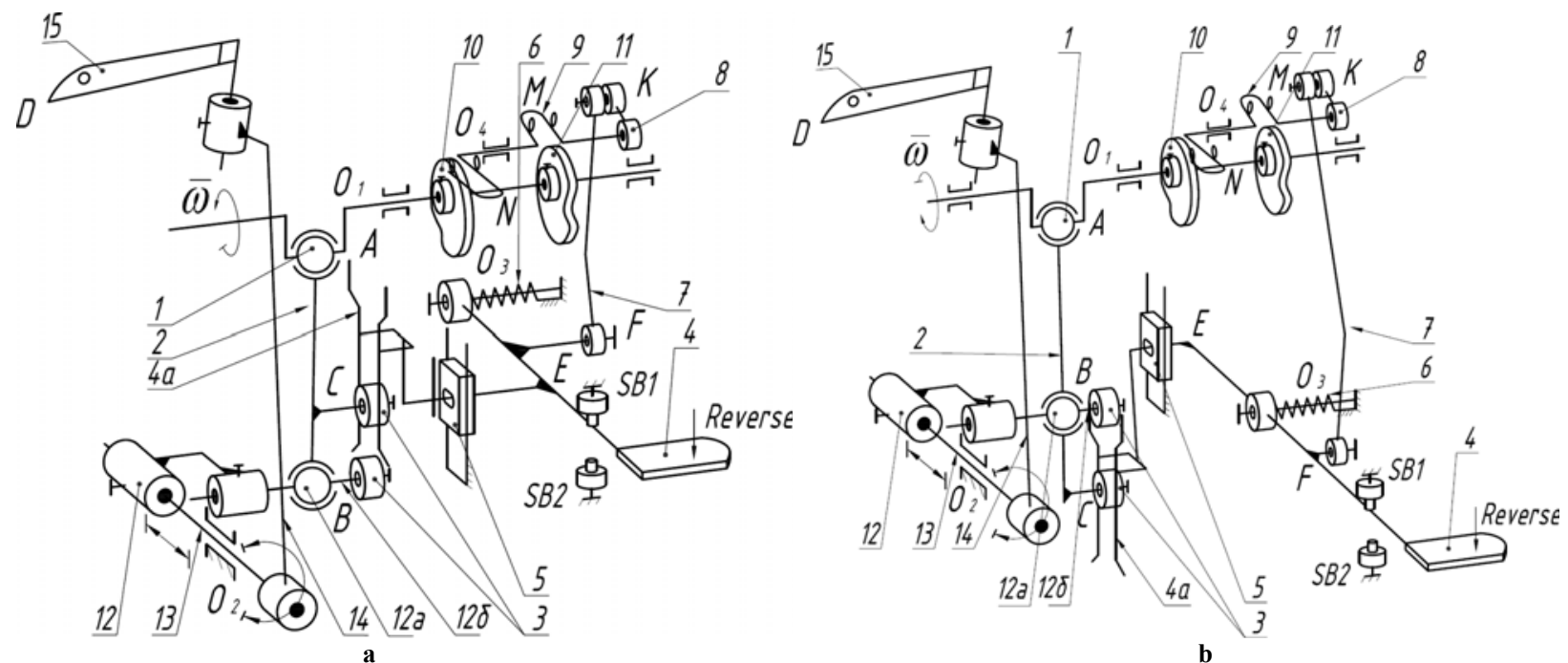

Fig. 2. Mechanisms of the looper and thread-giving unit: a - modification 1; b - modification 21 - the knee of the main shaft; 2 connecting rod; 3 - roller; 4 - lever; 5 - a slider; 6 - a spring; 7 - thrust; 8 - lever; 9 - a block of thread-fixing units; 10 - giving cam (straight-movement); 11 - giving cam (reverse); 12 - rocker; 12a - spherical finger; 12b - spherical finger process; 13 - looper shaft; 14 the holder of the looper; 15 - looper

The main task of the above proposed modernization is to determine the parameters of the mechanism, the hand lever device and the distance between the axis of the rocker arm and the connecting rod in the mechanism of the looper. The peculiarity of the work of the looper mechanism is that switching to another mode of operation must be performed at the extreme lower position of the needle, which requires the use of a sensor for monitoring the position of the main shaft (encoder).

In this case, if you exclude longitudinal movements of the looper along the line, it should be installed before the needles at a distance Z' (fig. 4) to ensure the capture of the loop when it interacts with the needles, which must be achieved when moving the lever 4 and the guide $4 \mathrm{a}$. The values of movement of the looper across the line Lx (fig. 4) and along the line Zx are determined by the method [6]. Parameters of the loop mechanism links: the value of the radius of the crank $r(\mathrm{OA})$ (fig. 5), the length of the rocker $\mathrm{L}_{\mathrm{O} 2 \mathrm{~B}}$ and the coordinates of the racks $\mathrm{O}_{1}$ and $\mathrm{O}_{2}$ are determined in part from constructive considerations, proceeding from the implementation of the required value and the law of the looper movement across the line Lx.

Parameter $\mathrm{l}_{\mathrm{BC}}(\mathrm{BC})$ defines the position of the connecting rod, which operates in a straight line with the necessary looper movement along the line $\mathrm{Zx}$, but also the constructive parameters of the mechanism (the possibility of alternate interaction of rollers 3 with direction $4 a$ ). Therefore, the calculation is reduced to determining the length of the connecting rod $1_{\mathrm{AB}}$. For the proposed variants 1,2 of the looper, the parameter $l_{\mathrm{BC}}$ is determined by the expressions (fig. 5):

$$
\begin{aligned}
& l_{B C_{1}}=\frac{Z_{x} \cdot l_{A B}}{2 \cdot r+Z_{x}}, \\
& l_{B C_{2}}=\frac{Z_{x} \cdot l_{A B}}{2 \cdot r},
\end{aligned}
$$

where $l_{\mathrm{AB}}-$ length of the connecting rod, $\mathrm{mm}$;

$r$ - radius of the knee of the main shaft, $\mathrm{mm}$;

$\mathrm{Z}_{\mathrm{X}}$ - the movement of the looper along the line, $\mathrm{mm}$;

$\mathrm{d}$ - roller diameter (height of the slider), $\mathrm{mm}$.

For both variants of the mechanism, the condition of connecting only one roller (slider) in the guides must also be performed:

$$
l_{B C_{1,2}} \geq 2 \cdot r+d .
$$




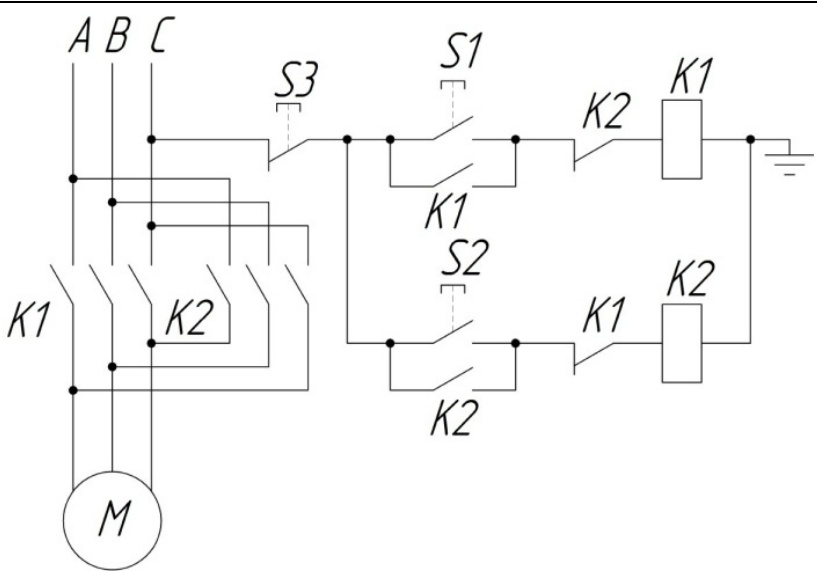

Fig. 3. Electrical control scheme of the electric motor reverse

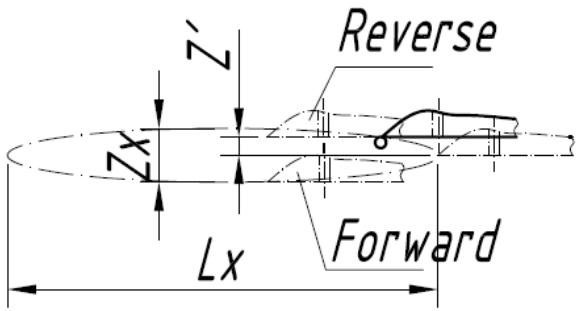

Fig. 4. Parameters of the looper interaction with needles in the forward and reverse movement of the material
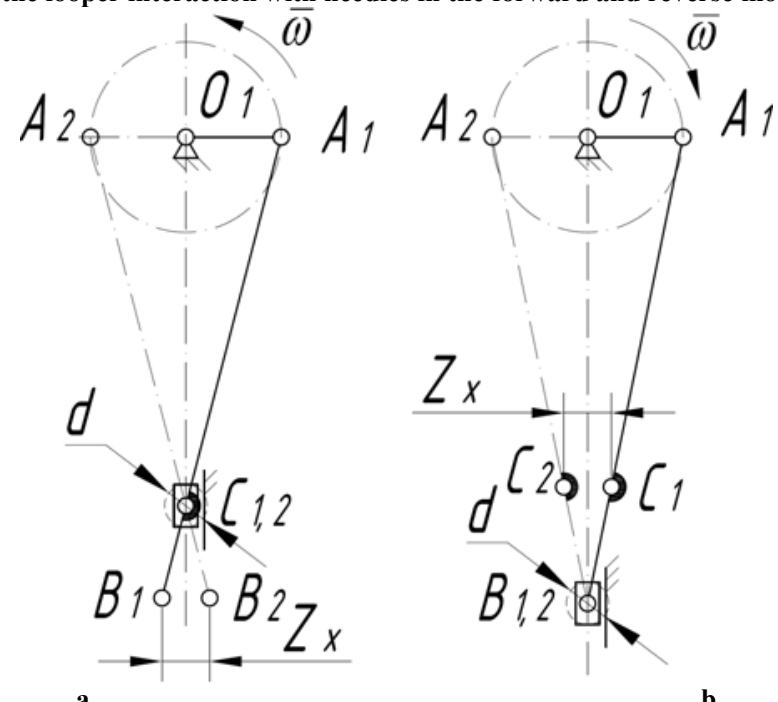

Fig. 5. Schemes of the parameter $h_{1,2}$ of the looper's mechanism: a - modification 1; b - modification 2

Substituting (3) into (1) and (2) we obtain the minimum required length of the connecting rod for both variants.

$$
\begin{aligned}
& l_{A B 1}=\frac{(2 \cdot r+d)\left(2 \cdot r+Z_{x}\right)}{Z_{x}}, \\
& l_{A B 2}=\frac{(2 \cdot r+d) 2 \cdot r}{Z_{x}} .
\end{aligned}
$$

Let's perform a calculation of the length of the connecting rod $1_{\mathrm{AB}}$ for the machine $876 \mathrm{PMZ}$ according to the following data: $\mathrm{r}=6 \mathrm{~mm}, \mathrm{Zx}=4 \mathrm{~mm}, \mathrm{~d}=6 \mathrm{~mm}$.

$$
l_{A B 1}=72 \mathrm{~mm}, l_{A B 2}=54 \mathrm{~mm} \text {. }
$$

Thus, only the second option can be used in this machine.

Extension of the length of the connecting rod $\mathrm{AB}$ by $21 \mathrm{~mm}\left(l_{\mathrm{AB} 876}=33 \mathrm{~mm}\right)$ can be made, because under the bottom of the connecting rod there is a deep crankcase with lubrication liquid.

To provide the position of the looper point $\mathrm{D}$ (fig. 2) in the reverse movement of the material, it is possible to get its offset by the lever $\mathrm{l}_{\mathrm{O} 3 \mathrm{E}}\left(\mathrm{O}_{3} \mathrm{E}\right)$ (fig. 6) of the rocker, whose length is determined by the expression:

$$
l_{O_{3} E}=\frac{Z^{\prime 2}+l_{B C_{1,2}}^{2}}{2 \cdot Z^{\prime}},
$$

where $Z^{\prime}$ - the value of looper movement along the line at the moment of snapping the loop, $\mathrm{mm}$. 


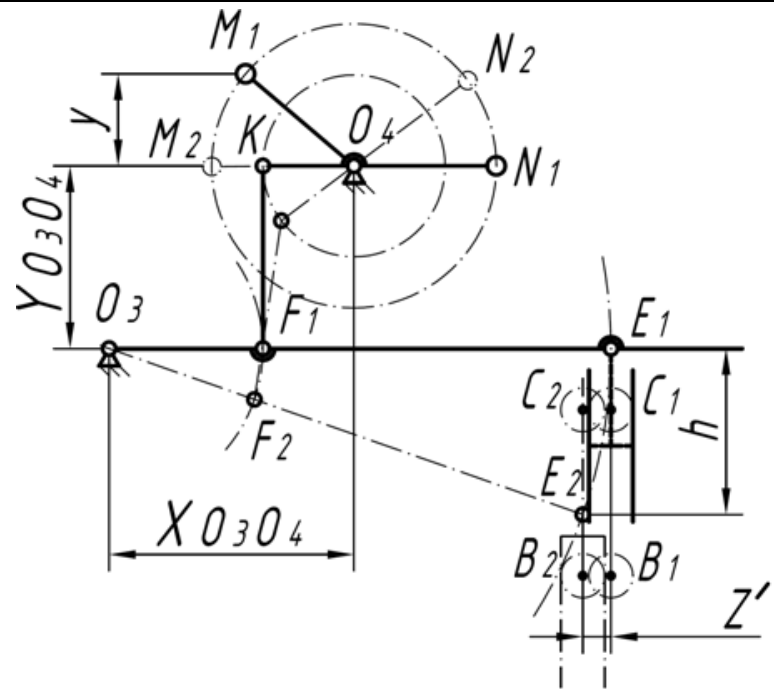

Fig. 6. Scheme of functional groups for turning off the looper movements across the line and switching the thread feed mechanisms expression:

The minimum value of $\mathrm{h}$ (fig. 6) - the movement of the guide $4 \mathrm{a}$ to ensure interaction is determined by the

$$
h \geq 2 \cdot r+d
$$

At the same time, the rocker should provide the switching of thread-fixers $\mathrm{N}$ and $\mathrm{M}$ (fig. 6) to the working position, which is achieved by the lengths of the shoulders $1_{\mathrm{O} 4 \mathrm{~K}}$ and $\mathrm{l}_{\mathrm{O} 3 \mathrm{~F}}$, and the minimum necessary amount of movement of the thread-fixing units, which eliminates the contact of the thread with the profile of the thread-giving cam.

The size of the shoulders $1_{\mathrm{O} 3 \mathrm{~F}}, 1_{\mathrm{O} 4 \mathrm{~K}}$ and connecting rod $1_{\mathrm{FK}}$ can be proposed constructively.

$$
l_{O_{4} K}=\frac{l_{O_{3} F} \cdot h}{l_{O_{3} E} \cdot y} \cdot l_{O_{4} M},
$$

where $y$-position of the thread-fixing unit relative to the surface of the thread-giving cam in the off condition ( $y=10 \mathrm{~mm}$ for a constructive row of sewing machines 876).

The coordinates of the rack $\mathrm{O} 4$ are determined by the expressions:

$$
X_{O_{3} O_{4}}=l_{O_{3} F}+l_{O_{4} K}, Y_{O_{3} O_{4}}=l_{F K}
$$

Conclusions. The proposed algorithm for upgrading the flat chain stitch sewing machine allows to significantly expand the range of technological operations that it can perform at a minimal cost.

\section{References}

1. JUKI : catalog. - M. : Ynlegmash, 1982.

2. Polukhin V.P. Shveynyye mashiny tsepnogo stezhka zarubezhnykh firm / Polukhin V.P., Reybarkh L.B. - M. : Legkaya industriya, 1979. - 344 p.

3. A.s. № 617499 SSSR MPK D05V 1/10. Sposob polucheniya dvunitochnoy tsepnoy strochki pri pryamom i obratnom eye peremeshchenii / V.A. Pishchikov. V.V. Egorov. - Opubl. 30.07.78. Byul. № 28. - 26 p.

4. A.s. № 825728 SSSR. MPK D05B 1/10. Shveynaya mashina dvokhnitochnogo tsepnogo sterzhka / V.A. Pishchikov. V.V. Egorov. - Opubl. 30.04.81. Byul. № 16. - 21 p.

5. JUKI Main\&Technology // Juki Corporation. URL: http/www.juki co. jp.

6. Pischikov V. A. Opredelenie hodov petlitelya mashin dvuhnitochnogo tsepnogo stezhka / V. A. Pischikov, N. N. Saraev, A. I. Trachun // Izvestiya vuzov. Tehnologiya legkoy promyishlennosti. - 1974. - № 3, № 4.

$$
\text { Рецензія/Peer review : 26.11.2018 p. Надрукована/Printed :15.2.2019 p. }
$$
Рецензент: д.т.н., проф. Орловський Б.В. 